\title{
Mentoring as Component of Continuous Professional Development Program: A Case Study of Multan District
}

\author{
Amna Sleem \\ Ph.D Scholar \\ Department of Education \\ International Islamic Universtiy,Islamabad
}

\begin{abstract}
:
Becoming a primary school teacher is a challenging assignment thatrequired skills and knowledge that are necessary to impact student performance. One tactic used to support primary school teachers is to assign experienced members of their profession astheir mentors. Mentor playsa significantrole inimproving teachers'professional developmentin their teaching profession.Intend outcomes of this paper wereto investigate the effectiveness of the procedures for the mentoring which are directed and organized by the regional teacher educatorsand to see its influence on the performance and dutiesof Teachers of primary school levels (PSTs) in Punjab.The extensive research study was descriptive.This study adopted the quantitative research method and utilized two research toolsquestionnaire and mentoring visit form.Outcomes of the studyexposed that the majority of the participants have a positive approach towardsan existingmentoring program. This study also provides evidence thatdue to the mentoring activities professional development of participants is enhanced. Major suggestions for the study were that mentorsshould be well trained and change their perspective towards contestants.
\end{abstract}

Keywords: mentoring and continuous professional development program.

\section{Introduction and review of related literature:}

Mentoring is a way to give support and guidance to a person in an appropriate way. A mentor is an experienced person who provides the services of support and guidance to the inexperienced person. The person who gets help and guidelines from the mentor is known as the mentee. Mentor works to increase the educational as well as professional development of the person (Gray,2005). Roehrig,Catherine,Turner, and Pressley (2008) discussed mentoring as the mentor who provides guidance in the personal life of the mentee and also helps a mentee to settle his/her own life in a better way. The positive understanding and warm rapportamongthe guiding training expert and the person who is getting that training experiencesare necessary for the successful fulfillment in the process of mentoring.

In the educational field, a mentor plays his role as a facilitator and helps to assist in the production of a new successful teacher. Interaction between the helper and the help seeker which are the mentor and the mentee respectively must be face to face to move forward the 
process of mentoring. A mentor must have the appropriate knowledge and command on the teaching strategies and the theories of learning while guiding the teachers to make changes in their teaching styles. He must be familiar with the innovative and advanced teaching strategies and methods of teaching. It will help the mentee to get advanced in their professional and educational scenario ( Ganser,2000).

Vazir\&Mehar(2010) discussed the situation of mentoring in Pakistan.In Pakistan, mentoring programs are started to mentor in-service teachers. It helps them to know about the role of teaching strategies and varying methods of teaching in the beneficial development of the students. The understanding between the mentor and the mentee is an essential part of this process. It is a gradual and systematic process.Halai (2006) proposed that the communication process and the interaction between the mentor and the mentee must be effective enough to deliver knowledge and information appropriately and effectively. Respect is an essential element in the process of mentoring. Respect must be given by both mentor and the mentee. There must be a sense of respect for ideas and concepts of each other. Negative criticism must be avoided from both sides to make a mentoring process successful. Reliability and the consistency between the knowledge of both mentor and mentee must be guaranteed.

Nowadays, the beliefs and the rituals of the teacher for their teaching professions are now to be changed due to the implementation and induction of the Continuous professional development programs.In these programs, the teachers must have to actively participate in the given activities to learn the new demands of the society towards their profession and duties. To provide effective Continuous professional development to the teachers of primary school levels DSD has produced the expert training processes as the main component of their training program. The current study explored the effectiveness of the expert training processes organized by region teacher educators for teachers of primary school levels. The main emphasis of the study was to analyze the change in teachers' performance and student learning due to mentoring activity(Akhlaq\& Saeed,2015).

Various studies that were conducted mainly werebased on mentoring and continuous professional development which helps to bring changes in the expert abilities of the teachers and also help them to bring advancements in their teaching styles by adopting various teaching strategies and teaching methods. The present study mainly focuses on the mentoring of the teachers to help them to develop a professional attitude among teachers. 


\section{Literature review:}

According to Pask and Joy (2007), the term mentoring is originated from Greek literature. This term means the experienced guide and the well- known experienced teacher who guides inexperienced persons. The mentor plays a role to groom the personality of the mentee. A mentor provides training and develops a sense of responsibility in the mentee.

Cantu \& Rogers, (2007) explains the term in a way that the mentor assists the mentee to reach at the top of his/her career professionally or academically. A mentor helps the mentee to move forward successfully.

\section{Forms of mentoring}

There are two common forms of mentoring as:

- Formal mentoring

- Informal mentoring

\section{Formal mentoring}

The formal mentoring process is a much more effective and reliable process as compared to the informal mentoring settings. Goals and objectives are appropriately and completely defined and set at the time of starting the mentoring process. There is easy access to the mentor by the mentee whenever he/she needs help from the mentor. In the formal mentoring setup the process has some time limits and the frequency is predefined by the mentor. Measurement of the results and the outcomes are possible (Wanberg, Welsh, and Hezlett,2003).

\section{Informal mentoring}

The informal mentoring process sometimes lasts throughout life. The outcomes and results are not clearly defined and not measurable. Goals and objectives are not defined. The allocation of the mentor is difficult in this process. The selection of a mentor is based on the personal interest of the mentee. Mentee feels difficulty accessing the mentor. The time duration in the informal mentoring process is not well defined and majorly depends on the mentor. There are no specified rules and regulations and the time boundaries to complete the process in a given period or a given set of rules ( Filstad, 2004). 


\section{Principles of the mentoring program}

Purdon (2003) explains the principles of the mentoring program are as under:

\section{Confidentiality}

The main and the primary duty of the experts is to keep the confidentiality of the process of mentoring. The relationship of respect and trust must have remained between the mentor and mentee during the whole process. The confidentiality of the data transferred to each other is necessary for a way that helps to develop a sense of enthusiasm and trust from both sides.

\section{Two-way process}

Mentoring is a two-way process that encircles and regulates between the mentor and the mentee. Transfer of knowledge, ideas, and guidance are regulated between both sides.

\section{Professional Values}

The process of mentoring has its professional values and professional ethics which guides the mentor and the mentee to respect the self-esteem of each other to give respect to the ideas and knowledge of each other. The point of view may be different from both parties but the sense of respect must be present during the whole process.

\section{Sense of independence}

The process of mentoring develops a sense of confidence and independence among the mentor and the mentee to share their views and problems independently.

\section{Relationship between mentor and mentee}

The mentoring process develops a healthy and fruitful relationship among mentors and the mentee. Stability in this relationship is always present. Job satisfaction is developed and the mentor also re-creates and refreshes his/her career during the process of mentoring according to the needs and demands of time and situation. 


\section{Benefits of the mentoring}

Hargraves\&Fullan,(2000) discussed the benefits of mentoring as it provides mental relaxation and satisfaction in the life of the mentee. Mentoring helps the mentee to achieve his/her goals successfully. Interpersonal communication skills are developed and polished by mentoring. It provides help to others in a way that improves the efficiency and potentials of the mentee and also improves the performance and professional skills of the mentee. Shadio(1996)explains that the process of mentoring motivates and encourages the mentee to take risks for the betterment of education systems and their professional development. It helps them to try new strategies and methods to improve their teachings.

The current study has the following objectives as

- To estimatethe procedures and the ways of mentoringas they steeredby district teacher educators.

- To evaluate the usefulness of various areas of mentoring as they are steered by district teacher educators.

Research questions of the study were given below

- Is district teacher educators conducted the mentoring process effectively?

- Do Subject mastery of the teachers at the primary school level is necessary for the minds of the mentors?

- Do after mentoring processes thebehavior of the teachers in the classroom change significantly?

- Is the mentor adopted an authoritative attitude towards primary school teachers?

\section{Methodology}

The descriptive nature of the study, the data analysis technique was quantitative. Duringthe current study, the target population was the whole primary school teachers of government schools of Punjab. StructuredQuestionnaire developed on 5 point scale developed by researcher andexpert training call letters which werearranged by DSD, Punjab used as a data-gathering tool for the current investigation. Based on nine indicators mentoring observation form evaluate teachers' performance.These indicators were records of the teachers including their memories, journals, and diaries, giving and glancing written activities, SLO(student learning outcome) (Taleemi Calendar), teaching and learning through 
activities and first-hand experiences, AV aid (support material), evaluation records of the students (oral/written), lesson plan devotion, student-teacher cooperation, and managing the classroom. These factors were scaled on 4 standards. The lower standard is $(0)$ and the peakstandard is (3). standard (0) stands for most bad actions, standard (1) fair actions, standard (2) good actions, and standard 3 excellent actions of the teachers at primary school levels.

\section{Data collection:}

For the structured questionnaire data of 323 participants were obtained through a simple random sampling technique and the weightage was 126 male and 197 females were participants from the Multan district. The sample of 323 primary school teachers and the weightage for this sample was 123 males and 200 females participantsfor the mentoring visit form.

\section{Data analysis:}

SPSS (Statistical Package for Social Science) software was used for the analysis of data received from the respondentsin terms of descriptive statistics.

Table 1:Analysisbased ona percentage of an observational sheet (mentoring visit form)

\begin{tabular}{|l|l|c|c|c|c|}
\hline $\begin{array}{l}\text { sr } \\
\text { no }\end{array}$ & \multicolumn{1}{|c|}{$\begin{array}{l}\text { Level (ndicators } \\
\text { )Poor }\end{array}$} & Level(1)fair & Level(2)good & Level(3)excellent \\
\hline 1 & Teachers diary & $3 \%$ & $20 \%$ & $47 \%$ & $30 \%$ \\
\hline 2 & $\begin{array}{l}\text { evaluation and } \\
\text { inspection of thehand- } \\
\text { written activities, }\end{array}$ & $1 \%$ & $28 \%$ & $46 \%$ & $25 \%$ \\
\hline 3 & $\begin{array}{l}\text { SLO(student learning } \\
\text { outcome) }\end{array}$ & $5 \%$ & $25 \%$ & $51 \%$ & $19 \%$ \\
\hline 4 & $\begin{array}{l}\text { Activity } \\
\text { Teaching and Learning, }\end{array}$ & $4 \%$ & $28 \%$ & $56 \%$ & $12 \%$ \\
\hline 5 & \begin{tabular}{l} 
Visual Aid (support \\
\hline
\end{tabular}
\end{tabular}




\begin{tabular}{|l|l|c|c|c|c|}
\hline & material), & & & \\
\hline 6 & $\begin{array}{l}\text { Students Assessment } \\
\text { (oral/written), }\end{array}$ & $1 \%$ & $22 \%$ & $41 \%$ & $36 \%$ \\
\hline 7 & $\begin{array}{l}\text { Adherence to Lesson } \\
\text { plan, }\end{array}$ & $1 \%$ & $25 \%$ & $40 \%$ & $34 \%$ \\
\hline 8 & $\begin{array}{l}\text { Interaction with the } \\
\text { students }\end{array}$ & $1 \%$ & $10 \%$ & $37 \%$ & $52 \%$ \\
\hline 9 & $\begin{array}{l}\text { Classroom } \\
\text { Management }\end{array}$ & $11 \%$ & $30 \%$ & $60 \%$ \\
\hline
\end{tabular}

Table 1 Depict the participants' performance on the mentoring call letters utilized by regional teacher educators. The outcome of the descriptive statistics exposed that most of the indicators rated on a good level such as records of the teachers including their memories(47\%), giving and glancing written activities (46\%), SLO(51\%), teaching and learning through activities and first-hand experiences, (56\%), AV aid (58\%), evaluation records of the students $(41 \%)$, and lesson plan devotion (40\%). While the other two indicators are highly rated as excellent i.e. Interaction with the students(52\%) and Classroom Management(60\%).

Table 2: Analysis based on descriptive statistics for questionnaire

\begin{tabular}{|c|c|c|c|c|c|c|c|c|c|c|c|}
\hline \multirow[t]{2}{*}{ Statement } & \multicolumn{2}{|l|}{$\mathbf{S A}$} & \multicolumn{2}{|l|}{$\mathbf{A}$} & \multicolumn{2}{|l|}{$\mathbf{N}$} & \multicolumn{2}{|c|}{ DA } & \multicolumn{2}{|c|}{ SDA } & mean \\
\hline & $\mathbf{F}$ & $\%$ & f & $\%$ & $\mathbf{F}$ & $\%$ & f & $\%$ & f & $\%$ & \\
\hline $\begin{array}{l}\text { Expertness in my } \\
\text { subject is gaining } \\
\text { by me through the }\end{array}$ & 135 & 42 & 136 & 42 & 20 & 6 & 19 & 6 & 13 & 4 & 4.28 \\
\hline
\end{tabular}




\begin{tabular}{|c|c|c|c|c|c|c|c|c|c|c|c|}
\hline $\begin{array}{l}\text { mentoring } \\
\text { programs. }\end{array}$ & & & & & & & & & & & \\
\hline $\begin{array}{l}\text { Mentoring } \\
\text { enables me to teach } \\
\text { effectively. }\end{array}$ & 74 & 23 & 73 & 22 & 10 & 3 & 13 & 4 & 153 & 47 & 2.70 \\
\hline $\begin{array}{l}\text { Through } \\
\text { mentoring, I use } \\
\text { different ways to } \\
\text { solve my classroom } \\
\text { problems and } \\
\text { issues. }\end{array}$ & 108 & $33 \%$ & 155 & $48 \%$ & 25 & 7 & 18 & 5 & 17 & 5 & 4.01 \\
\hline $\begin{array}{l}\text { I am getting } \\
\text { prepared for my } \\
\text { professional } \\
\text { development and } \\
\text { improvement } \\
\text { through mentoring. }\end{array}$ & 104 & 32 & 162 & 50 & 28 & 9 & 14 & 4 & 15 & 5 & 4.01 \\
\hline $\begin{array}{l}\text { The use of different } \\
\text { teaching tactics and } \\
\text { materials according } \\
\text { to the situation is } \\
\text { learned by me } \\
\text { through mentoring. }\end{array}$ & 118 & 36 & 158 & 49 & 2 & 7 & 14 & 4 & 12 & 4 & 4.10 \\
\hline $\begin{array}{l}\text { A suitable and } \\
\text { feasible } \\
\text { environment is } \\
\text { conducted by the } \\
\text { mentoring } \\
\text { programs for me. }\end{array}$ & 64 & 20 & 75 & 23 & 34 & 11 & 39 & 12 & 111 & 34 & 2.82 \\
\hline
\end{tabular}




\begin{tabular}{|c|c|c|c|c|c|c|c|c|c|c|c|}
\hline $\begin{array}{l}\text { Reflective and } \\
\text { critical thinking } \\
\text { skills } \\
\text { encouraged and } \\
\text { promoted in me by } \\
\text { mentoring. }\end{array}$ & 91 & 28 & 162 & 50 & 28 & 9 & 26 & 8 & 16 & 5 & 3.89 \\
\hline $\begin{array}{l}\text { Mentors possess } \\
\text { authoritative } \\
\text { behavior toward } \\
\text { me. }\end{array}$ & 34 & 11 & 90 & 28 & 32 & 10 & 98 & 30 & 69 & 21 & 2.76 \\
\hline $\begin{array}{l}\text { With the help of } \\
\text { mentoring } \\
\text { programs, my } \\
\text { teaching abilities } \\
\text { and the skills are } \\
\text { improved. }\end{array}$ & 96 & 30 & 137 & 43 & 32 & 10 & 32 & 10 & 26 & 8 & 3.76 \\
\hline $\begin{array}{l}\text { Through mentoring } \\
\text { programs, my } \\
\text { confidence } \\
\text { increased day by } \\
\text { day. }\end{array}$ & 125 & 39 & 129 & 40 & 20 & 6 & 30 & 10 & 19 & 5 & 3.75 \\
\hline $\begin{array}{l}\text { Beneficial feedback } \\
\text { responses are } \\
\text { always gained by } \\
\text { me from my } \\
\text { mentor on time. }\end{array}$ & 48 & 15 & 75 & 23 & 39 & 12 & 84 & 26 & 77 & 24 & 2.79 \\
\hline $\begin{array}{l}\text { Pedagogical } \\
\text { training skills are }\end{array}$ & 86 & 26 & 151 & 47 & 22 & 7 & 43 & 13 & 21 & 7 & 3.74 \\
\hline
\end{tabular}




\begin{tabular}{|c|c|c|c|c|c|c|c|c|c|c|c|}
\hline $\begin{array}{l}\text { learned by the } \\
\text { regional education } \\
\text { teachers through } \\
\text { mentoring } \\
\text { programs }\end{array}$ & & & & & & & & & & & \\
\hline $\begin{array}{l}\text { Regional teacher } \\
\text { educator } \\
\text { performing as the } \\
\text { role model }\end{array}$ & 49 & 15 & 85 & 26 & 35 & 11 & 76 & 24 & 78 & 24 & 2.85 \\
\hline $\begin{array}{l}\text { I make the } \\
\text { professional growth } \\
\text { program time } \\
\text { beneficial for me }\end{array}$ & 74 & 23 & 166 & 51 & 35 & 11 & $31 \mathrm{~s}$ & 10 & 17 & 5 & 3.77 \\
\hline $\begin{array}{l}\text { Through mentoring } \\
\text { programs, I learned } \\
\text { the use of AV aids } \\
\text { at a minimum cost. }\end{array}$ & 89 & 28 & 156 & 49 & 20 & 6 & 35 & 11 & 23 & 7 & 3.78 \\
\hline
\end{tabular}

Table 2 Depict the participants' responsestothe structured questionnaire collected by the investigator. We can see that most of the participants have a positive attitude towards the mentoring process but they disagreed that A suitable and feasible environment is conducted by the mentoring programs for me and beneficial feedback responses are always gained by me from my mentor on time.The majority of the participants agreed that the mentoring processis effective for enhancing their professional development.

\section{Conclusions:}

Conclusions were drawn from the analysis of the problem and presented in the following form. 
- Mentor performs his duty very well in helping the teachers at the primary school level to make their classroom problems solvable for them and he was highly efficient in his field especially in pedagogy.

- The activity of mentoring developed reflective thinking among teachers and upgraded their teaching efficiency in their classrooms.

- Confidence among teachers enhanced due to the process of mentoring.

- An attitude of the mentor showed that he was not concerned about the teachers and failed to provide them a feasible and suitable environment.

- Teachers do not possess regional teacher educators as their role models because they do not play any role in providing a supportive environment for their professional growth and development.

- Mentoring visit formoutcomes alsoexposed that participants'performance enhanced due to the mentoring process.

\section{Discussion:}

The focus of my research is on the contemporary issue of the teacher training program conducted by the directorate of staff development. Mentoring is a significant part of a teacher training program nowadays. Vitalconclusionsdisplay that mentorshave command in his area of subject and teaching skills. Primary school teachers did not receive in time feedback from their mentor. The studyexhibited that primary school teachers' performance enhanced due to the mentoring program and they grow professionally in a better way. The outcome of the study was supported by Vazir\&Mehar (2010), that the mentoring program expands primary school teachers' pedagogical and andrological skills in their classrooms and established better interaction between mentor and mentee.Roeshrig,Catherine,Turner, and Pressley (2008) conclude that the mentoring program improves if better interaction between mentor and mentee has settled. This study showed that the attitude of the mentor was authoritative towards Primary school teachers who were not considered by previous studies. Different roles adopted by mentors are not considered in this study which was an important factor in previous studies. There is a lack of financial resource availability for mentors. Free visual aids and supporting material should be provided by directorates of staff development to primary school teachers according to their needs. Another study supported the conclusion of this studyCornell (2003)exposed that process of mentoring enhanced the communication skills of the menteeand helped themin their classroom for effective communication with their 
students.Gardiner (2008) represented that the mentoring program is more beneficialfor junior teachers rather than for senior teachers and they stressed online and informal mentoring,however, the current study focused on the job mentoring process.

\section{Recommendations:}

Recommendations associated with the problem of the study for future researchers were,

- Mentors should be role models for manatee and givevaluable and timely feedback to them.

- A mentor attitude should adopta positive attitude towards primary school teachers and become their friend, guider, and support system.

- For making the mentoring process more effective appropriate training concerningbehavior management should be conducted for District teacher educators.

- The process of Mentoring should enrichthe teaching skills of teachers with free visual aids and additionalresources and supporting material should be provided to themso that they can efficiently utilize their teaching skills inthe classroom. 


\section{References}

1. Akhlaq, M., Iqbal, M. Z., \&Jumani, N. B. (2015).Mentoring process a stimulus for professional development of primary school teachers in Punjab, Pakistan. Mediterranean Journal of Social Sciences, 6(3 S1), 146.

2. Cantu, A. G., \& Rogers, N. M. (2007).Creating a mentoring and community culture in nursing. Hispanic Health Care International, 5(3), 124-127.

3. Cornell, C. (2003). How Mentor Teachers Perceive Their Rolesand Relationships in a field-basedTeahcer-Training PRogram. Education, 124(2).

4. Filstad, C. (2004). How newcomers use role models in organizational socialization. Journal of workplace learning.

5. Ganser, T. (2000).An ambitious vision of professional development for teachers. NASSP bulletin, 84(618), 6-12.

6. Gardiner, C. E. (2008). Mentoring: towards an improved professional friendship (Doctoral dissertation, University of Birmingham).

7. Gray ,S.L.(2005).An Enquiry into Professional Development for Teachers.London:Farbrain Foundation.

8. Halai ,Anjum.(2006).Mentoring in service teachers:Issues of role diversity.Teaching and Teacher Education,22,6,700-710.doi.org/10.1016/j.tate.2006.03.007

9. Hargreaves, A., \&Fullan, M. (2000).Mentoring in the new millennium. Theory into practice, $39(1), 50-56$.

10. Pask, R., \& Joy, B. (2007). Mentoring-coaching: A guide for education professionals. McGraw-Hill Education (UK).

11. Purdon, A. (2003). A national framework of CPD: continuing professional development or continuing policy dominance?. Journal of Education Policy, 18(4), 423-437.

12. Roehrig, D .Alysia., Bohn, M. Catherine., Turner, E. Jeannine.,\& Pressley, Michael .(2008). Mentoring beginning primary teachers for exemplary teaching practices .Teaching and Teacher Educatio, 6(1), 319.doi.org/10.1016/j.tate.2007.02.008

13. Shadio,L.(1996).Rembering a Mentor.Clearing House,69 5,277 279. 
14. Vazir,N.,\&Mehar,R.(2010).Mentoring in teacher education:Building nurturing contexts and teaching communities for rural primary teachers in Sindh,Pakistan.Journal of Educational Research,13(1),123-143.

15. Wanberg, C.R.,Welsh ,E.T.,\&Hezlett ,S.A.(2003).Mentoring Research:A Review and Dynamic process Model.Research in Personal and Human Resource Management,22,39-124. 